\title{
Student Work Sheet Development Based on Cooperative Learning Course Statistics and Probability in the University Pembinaan Masyarakat Indonesia
}

\author{
Rini $^{1 *}$, Yulia Tanjung Tiara ${ }^{2}$ \\ ${ }^{i}$ University pembinaan masyarakat Indonesia, Jl. Teladan No. 15, Medan City and 20214, Indonesia \\ ${ }^{2}$ University pembinaan masyarakat Indonesia, Jl. Teladan No. 15, Medan City and 20214, Indonesia \\ rinitapten@yahoo.co.id*; 2 tiarabortanlia@gmail.com
}

\begin{tabular}{ll} 
ARTICLE INFO & ABSTRACT \\
\hline $\begin{array}{l}\text { Article history: } \\
\text { Accepted }\end{array}$ & To enhance the learning achievement of each student the lecturer of \\
& the course are required to find and implement appropriate teaching \\
& methods and effective in each of the learning process so that every \\
& learning objectives and teaching can work as expected. Cooperative \\
& learning is a form of learning by students to learn and work \\
& collaboratively in small groups whose members consist of four to six \\
Keywords: & people with a heterogeneous group structure.
\end{tabular}

Student Worksheet

Cooperative learning

Statistics and probability

\section{Introduction}

One of the subjects that must be taken by a student of civil engineering at Pembinaan Masyarakat Indonesian University. Statistics and probability Course discusses the basic of statistics and probability, presentation of data in tables and charts, the size of the concentration, location and dispersion, as well as the size of the slope and kurtosis, normal distribution and usefulness, hypothesis testing, analysis regression and correlation. If seen the material to be learned, then studied statistics and probability requires students to have knowledge of certain prerequisites. The knowledge including knowledge of the data that you see in their daily life, including calculating logarithms of algebraic operations.

To enhance the learning achievement of each student the lecturer of the course are required to find and implement appropriate teaching methods and effective in each of the learning process so that every learning objectives and teaching can work as expected. The purpose of this study was to assess how to effect the method of learning by using student worksheets based cooperative learning.

\section{Related Studies}

Learning with Cooperative Learning is a learning group with the number of learners 4-5 people with ideas to motivate each other among its members to help each other in order to achieve a maximal learning objectives.

\section{A. Cooperative learning}

Cooperative learning is a form of learning by students to learn and work together in small groups of collaborative members consist of four to six people with a heterogeneous group structure. In cooperative learning more emphasis on the process of cooperation in groups where the objectives to be achieved not only the ability of mastering learning materials, but also an element of cooperation for the control of these materials. One of the main principles of learning is cooperative learning and discovery-based learning activities, in which students are easier to find and understand concepts that are difficult if they were discussing the issue with friends. In cooperative learning methods of students learning through peer interaction that is more capable. To enhance the learning achievement of each student the lecturer of the course are required to find and implement appropriate teaching 
methods and effective in each of the learning process so that every learning objectives and teaching can work as expected. The purpose of this study was to assess how efektifkan method of learning by using student's worksheets based cooperative learning.

\section{B. Characteristics of cooperative learning}

Characteristics of cooperative learning is the students are divided into small groups. Members of the group consisted of students with varying abilities; include high, medium and low. Members are heterogeneous, both differences in ethnicity, gender, socioeconomic background, and others.

- Students learn in her group cooperative learning to master academic material. The task of the group is to help each other friends group of their learning to achieve mastery.

- The award system is more oriented to the group of the individual.

\section{Stages cooperative learning}

As in any implementation of cooperative learning can be seen from table 1 below:

Table 1. Cooperative learning stages

\begin{tabular}{lll}
\hline No. & \multicolumn{1}{c}{ Activity } & \multicolumn{1}{c}{ Explanation } \\
\hline 1 & $\begin{array}{l}\text { The provision of teaching } \\
\text { materials } \\
\text { organizing student } \\
\text { Into the study group }\end{array}$ & $\begin{array}{l}\text { Lecturers explain the purpose of learning and teaching } \\
\text { materials thoroughly on target achievement. } \\
\text { Organizing of lecturers help students to form study } \\
\text { groups consisting of } 4 \text { to } 6 \text { students. So the transition } \\
\text { can be run efficiently. }\end{array}$ \\
$\begin{array}{l}\text { Guiding and supervising the } \\
\text { group Learning }\end{array}$ & $\begin{array}{l}\text { Lecturers guide the study groups by the time they } \\
\text { complete the questions given in the form of student } \\
\text { worksheets and kept an eye on that order is maintained. }\end{array}$ \\
\hline
\end{tabular}

\section{Method of the Research}

In this research to be developed is a device in the form of student's worksheets learning cooperative learning based on statistics and probability course valid, effective and practical. The data needed to achieve these objectives is the data: (1) The results of student learning, (2) the response of students using a questionnaire, and (3) expert opinion obtained by using sheets of expert judgment and (4) the results of observations of activity lecturers were obtained using a sheet observation. Fourth of data in the form of numbers. Thus, the researchers used a quantitative approach to obtain research data was then used to achieve the research objectives.

\section{Results and Discussion}

From the analysis of questionnaires that have been distributed to students as a subject of research and observation research professor of the obtained results below.

\section{A. Questionnaire observation of lecturers}

Questionnaire observations faculty as a researcher on the activities of 20 students as research subjects to assess the activity and effectiveness of the use of cooperative learning in problemsolving worksheets, students can be seen in Table 2 as follows: 
Table 2. The questionnaire observations lecturer

\begin{tabular}{lccc}
\hline No & good & is not good & is not good \\
\hline 1 Respondents & 19 & 1 & 0 \\
2 Percentage & $95 \%$ & $5 \%$ & $0 \%$
\end{tabular}

From the results of the above percentages can be concluded that the use of cooperative learning in the student's problem-solving worksheets can be used as a good learning method because the value of the percentage is above $60 \%$ so that cooperative learning is declared valid

\section{B. Student questionnaire responses}

Student questionnaire responses regarding the use of cooperative learning methods in solving problems on a worksheet where the student questionnaire distributed to 20 students who serve as research subjects to assess interest in each student toward cooperative learning methods can be seen in Table 3 as follows:

Table 3. Questionnaire student response

\begin{tabular}{llcc}
\hline No & good & less & bad \\
\hline 1 Respondents & 20 & 0 & 0 \\
2 Percentage & $100 \%$ & $0 \%$ & 0 \\
\hline
\end{tabular}

From the results of the above percentages can be concluded that the use of cooperative learning in the students problem-solving worksheets can be used as a good learning method because the value of the percentage is above $60 \%$ so that the response of students to cooperative learning methods declared invalid.

\section{Conclusion}

From the analysis conducted during the study process can be concluded as follows:

1. Percentage of observation tutor questionnaire results above can be seen that the use of cooperative learning in problem-solving worksheets students have a percentage value of $90 \%$, while the percentage of student responses obtained percentage value was $100 \%$. This suggests that cooperative learning methods can be used as one method of learning is good.

2. Methods of cooperative learning can increase student interest in learning any which can also increase the value of students' academic achievement.

3. Methods of cooperative learning can enhance the courage and self-confidence of students due to implement cooperative learning presentation system.

4. By learning cooperative learning methods to teach students how to work together in study groups. Where each student can meet and exchange ideas in solving student worksheets together.

\section{Recognition}

Acknowledgment The authors would like to thank to the Kemenristek Higher Education for funding this research through the program "Beginner Lecturer Research Grants 2019".

\section{Reference}

[1] Anggraini. 2014. Development of worksheets students (LKM) based on perkuliaham pbl ordinary differential equations. [Online] .Tersedia: http: //repository.uksw.edu/bitstream/123456789/ 4629/2 / pros_rahmi,\% 20v\% 20anggraini,\% 20melisa_pengembangan $\%$ 20lembar\% 20kerja_fulltext.pdf 
[2] A. Suprijono, "cooperative learning: theory and applications PAIKEM," in the theory of cooperative learning for application in Indonesia, Bandung, library students, 2009, p.190 things.

[3] D. Siswoyo, "cooperative learning," May 08, 2013. [online]. Available: http://dedi26.blogspot.com/2013/05/pengertian-pembelajaran-kooperatif.html.[accessed 25 July 2013].

[4] Rizka dhini kurnia. 2014. Development of a model-based learning cooperative learning to improve student learning motivation and improving the quality of graduate alumni of Fasilkom Unsri based e-learning (case study: web programming course). Proceedings Online ISSN: 2355-4614. [on line]. Available: (http://eprints.unsri.ac.id/5393/1/774-2481-1-pb.pdf). [Accessed 01 August 2018].

[5] Suryana. 2015. Analysis of model implementation pace in mathematical statistics course. [Online] .tersedia: (http://journal.lppmunindra.ac.id/index.php/jkpm/article/d ownload / 898/837) [accessed 07 August 2018].

[6] T. "impelemntasi computer-aided model of cooperative learning in the learning of mathematics education $\mathrm{i}$ in PGSD students," the journal of education, vols. Vol 39, no 2, no. Education, pp. 119-128, 2009.

[7] Thiagarajan, s. Semmel, ds. Semmel, m. 1974. Instructional development for training teachers of exceptional children. A sourse book. Indiana: Indiana University

[8] Tri dyah prastiti. 2017. Development react based student worksheet (Relating, experiencing, applying, cooperating, Transferring) the statics tutorial in open university education. Proceedings. ISSN $\quad$ 2088-687x. [on line]. Available: (https://media.neliti.com/media/publications/177580-id-pengembanganlembar-kerjamahasiswa-berb.pdf). [Accessed 01 August 2018].

[9] Y. Yorozu, M. Hirano, K. Oka, and Y. Tagawa, "electron spectroscopic studies on magnetooptical media and a plastic substrate interface," IEEE transl. J. Magn. Japan, vol. 2, pp. 740741, August 1987 [Digests 9th Annual Conf. Magnetic Japan, p. 301, 1982]. 